\title{
Effect of Sulfur on Sugarcane Yield and Quality at the Heavy Clay Soil "Vertisols" of Sudan
}

\author{
Abdelrahman M. Ahmed Hamid ${ }^{1}$, Yassin M. Ib. Dagash,", \\ ${ }^{1}$ Department of Agronomy, Research and Development Department, KSC, Sudan \\ ${ }^{2}$ Department of agronomy, Sudan University of Science and Technology \\ *Corresponding Author: dagash@sustech.edu
}

Copyright (C) 2014 Horizon Research Publishing All rights reserved.

\begin{abstract}
The experiment was laid out in randomized complete block design (RCBD) with four replications to evaluate the effect of sulfur in the form of ammonium sulfate on growth, yield and quality of sugarcane. Sulfur is a deficiency common problem in such soils. Application of fertilizers was at the rate of 164 and $55 \mathrm{~kg} /$ ha nitrogen in the form of urea supplemented with ammonium sulfate nitrogen dose of $164 \mathrm{~kg} / \mathrm{ha}$ and phosphorus in the form of tri-super phosphate respectively "normal practice" and 0.00, 28.00, $57.00,86.00$ and $114.00 \mathrm{~kg} \mathrm{~S} /$ ha. The results showed that Sulfur had a positive impact on sugarcane yield/ha, There was a clear increase in production compared to (control) and the negative impact was on plant density and plant height. Control gave the highest yield of sugar/ ha, then 114, 28, 57 and 86 respectively. There were insignificant differences between the means of the internodes number and plant height of all treatments. The Sulfur application gave significantly different in the total soluble solids (Brix\% cane) but there were insignificant differences among means of (Pol\% cane, Fiber $\%$ cane, extract reduced sucrose ERSc, purity $\%$ and moisture\%).
\end{abstract}

Keywords Sugarcane, Sulfur, Yield, Quality, Fertilizers

\section{Introduction}

Sugarcane belongs to the grass family (Poaceae), an economically important grain plant family that includes maize, wheat, rice, and sorghum and many forage crops (Jannoo et al., 2007). It is a large, perennial, tropical or subtropical grass widely grown in a zone around the world within $30^{\circ}$ of the Equator. It is usually vegetatively propagated from auxiliary buds on the stem (or stalk) cuttings. The first, "plant" crop is generally harvested from 28 to 57 Months after planting; thereafter, "ratoon" crops may be harvested at shorter to equal time periods. Ratoon crops may be grown in several cycles. The large, mature stalks contain juice of 9 to $18 \%$ sucrose. The juice is extracted by crushing the stalks with high-pressure rollers in a mill. Sucrose is crystallized from the juice after water is removed by boiling to produce a brown-colored raw sugar. White sugar is produced by re-crystallization from raw sugar in a refinery (Ming et al., 2006). The main sugarcane growing countries include: India, Brazil, Cuba, Australia and Mexico (Ali, 1986).

The general sugarcane fertilizers recommendations have been transformed in to a set of a site/soil- specific that recommendations are promoted with an integrated or (whole-of system) approach to nutrient management (BL et al., 2005). A mineral element is considered to be essential to plant growth and development and involved in plant metabolic function and the plant cannot complete its life cycle correctly without this element. Usually, the plant exhibits a visual symptom indicating a deficiency in a specific nutrient, which normally can be corrected or prevented by supplying that nutrient. Visual nutrient deficiency symptoms can be caused by many other plant stress factors, therefore; caution should be exercised when diagnosing deficiency symptoms (Tisdale et al., 1985).

Sulfur is one of the 16 elements essential to crop production, and it is essential for maximum crop yield and quality, often ranked behind only nitrogen, phosphorus and potassium in importance (Jeschke and Diedrick, 2010).

Sulfur is becoming more of a limiting nutrient in crop production than in the past. The reasons for this increasing need include: higher crop yields which require more sulfur, increased use of high analysis fertilizers containing little or no sulfur; reduced amounts of atmospheric sulfur fallout in rainfall; and reduced soil sulfur reserves from organic matter losses due to mineralization and erosion (AW, $\mathrm{PW}$ and $\mathrm{JH}$, 2005; Ceccotti, 1996). Sulfur plays an important role in the plant's metabolism, and required for amino acids, proteins and photosynthesis. Sulfur deficiencies are often confused with Nitrogen deficiencies. Symptoms of Sulfur deficiency appear as: Stunted plant growth, General yellowing of leaves. In less severe $\mathrm{S}$ deficiency situations, visual symptoms may not be apparent, but both yield and quality of crops will be affected (Ceccotti, 1996). Sulfur concentrations in crop plants should range between 0.2 and 0.5 percent. The sulfur status of crops is best diagnosed by plant analysis, The 
concentration of $\mathrm{S}$ in plant tissue is commonly used as an aid in diagnosis of deficiency, and the establishment of critical concentration values is an essential prerequisite for the interpretation of leaf analysis (Randall et al., 1997; Shrift, 1961).

Sugarcane exhibits luxury consumption and removes a considerable quantity of $\mathrm{S}$ from the soil. A hundred ton crop of cane contains about $47.6 \mathrm{~kg} \mathrm{SO}_{4}$ (Ali, 1986; Humbert, 1968)

Re-evaluation of the fertilization program was required to cope with the influx of new high yielding cultivars and the improved management level which included well land preparation, proper irrigation, good weed control and improvement on other agronomic practices. This study aims at determining the sulfur level best suited for high cane and sugar production under the current husbandry standard.

\section{Materials and Methods}

\subsection{Site Characterizations}

The soil is brown heavy clay and classified as true vertisols, the upper $60 \mathrm{~cm}$ of the soil profile is a cracking clay with $40-60 \%$ clay content, the dominant clay mineral is montmorillonite. Bulk density $1.60-1.70 \mathrm{gm} \mathrm{cm}^{-3}$, ninety percent of the upper horizon has an electric conductivity less than $2 \mathrm{mmhos} / \mathrm{cm}$., the organic carbon ranges between 0.30 $0.40 \%$, the available $\mathrm{P}$ ranges between $0.03-11.50 \mathrm{ppm}$, available K $170-350$ ppm, CEC 58-61, the exchangeable sodium percent (ESP) is less than 15 , and the soil $\mathrm{pH}$ ranges between $7.0-8.50$.

\subsection{The Experiment}

The experiment was conducted in season 2011/28 to study the effect of different levels of sulfur on sugarcane yield and quality. The levels of sulfur were $0.00,28.60,57.00,85.70$ and $114 \mathrm{~kg} \mathrm{~S} / \mathrm{ha}$. The test cultivar R 579 which occupies about $20 \%$ of the commercial sugarcane fields at Kenana Scheme. The treatments were laid out in a randomized complete block design (RCBD) replicated four times. The subplot area was 4 rows $\times 10 \mathrm{~m} \times 1.50 \mathrm{~m}(60 \mathrm{~m})^{2}$. The planting and harvesting dates from Feb. 2012 to March 2013, The irrigation interval was within the recommended range of 10-12 days. The land preparation was: uprooting of previous crop stools, deep plowing, harrowing, leveling, and furrowing at a distance of $1.50 \mathrm{~m}$. Similar to the standard practice, Nitrogen was applied one dose $164 \mathrm{~kg} \mathrm{~N} / \mathrm{ha}$ in the form of urea completed by ammonium sulfate as indicated dose at the planting date time. Phosphorus applied at the planting date also at the rate of $54.80 \mathrm{~kg} \mathrm{P}_{2} \mathrm{O}_{5} /$ ha in the form of TSP. Soil samples, to determine its major characters, were taken before planting and after harvesting dates.

Growth and yield components: height, thickness and number of millable cane stalk per unit area were measured at monthly interval for 4 months in 5 plants tagged in each subplot.

Leaf tissue samples composed of the leaves number 3, 4, 5 and 6 of 5 stalks from each plot were collected at 6 month age of cane. The blades were separated for $\mathrm{N}$ determination and the sheath for $\mathrm{P}, \mathrm{K}$ and $\mathrm{S}$ determinations. The cane was harvested and the yield determined at age 13Months for the plant crop cycle. Ten stalk samples were collected and the sugar analyzed following the ICUMSA system for determination of pol\%, Brix $\%$ and fiber $\%$. Yield and yield component data parameters were statistically analyzed.

\section{Results and Discussion}

\subsection{Yield Components}

\subsubsection{Plant Height $(\mathrm{cm})$}

Plant height is a main parameter of growth and yield. Although an internodes property (length, thickness and shape) is varietal characters, yet the rate of elongation and length of the internodes and hence plant height provide information about the general condition of the crop. In table2 application of sulfur did not affect plant height in any particular trend. But in general, the application of sulfur on sugarcane Variety R 579 is not affected in any dose because the control is longer than any additional sulfur dose in this experiment. The analysis of variance also showed that the effect of applied sulfur on stalk height was not significant for all sulfur rates.

\subsubsection{Plant Density}

The number of plant density is also a major constituent of cane yield. Tillering which provides the plants with the optimum number of stalks needed for a good yield is known to be affected by the availability of various nutrients. The plant population ranged from about 86.19 to 42.28 thousand / hectare. Plant population count for different sulfur levels are shown in table 1 . The analysis of variance showed that there were no significant differences among treatments. Hence the plant population did not respond significantly to sulfur application. But plant population was slightly increased with an increased in sulfur levels 28 and $57 \mathrm{~kg} \mathrm{~S} /$ ha respectively and then decreased under no sulfur (control). These effects in an increase and decrease didn't reach a significant level. Treatment (28 kg S/ha) caused slight increase, but it was statistically insignificant.

\subsubsection{Stalk Diameter $(\mathrm{cm})$}

The analysis of variance showed no significant differences among treatments. It was clear from these data that the stalk diameter was not affected by sulfur application. Stalk diameter measurements were shown in table 2 .

\subsection{Cane Quality}

The cane quality parameters include percent sugar ( $\mathrm{Pol} \%$ cane), (Fiber\% cane), estimated recoverable sugar (ERSc), (Purity) and (Moisture). The results of the first tow 
parameters were shown in table 3 . Analysis of variances of these parameters showed no significant differences among treatments, while no significant differences also among other cane quality parameters included ERSc, Purity and Moisture. Analysis of variance of Brix $\%$ cane in table 3 showed a significant difference among treatments. There is a significant difference between treatment $86 \mathrm{~kg} \mathrm{~S} / \mathrm{ha}$ and all other treatments, significant different between treatment 57 $\mathrm{kg} \mathrm{S} / \mathrm{ha}$ and treatment $0.00 \mathrm{~kg} \mathrm{~S} /$ (control). There is no significant difference between treatment $28.6,114 \mathrm{~kg} \mathrm{~S} / \mathrm{ha}$ and treatment 0.00 (control). According to these results, the treatment $0.00 \mathrm{~kg} \mathrm{~S} / \mathrm{ha}$ (control) was the best one because it gave a higher Brix contents.

Table 1. Effect of sulfur levels on sugarcane, yield TCH, yield TSH and plant population, Variety R 579

\begin{tabular}{cccc}
\hline S levels kg/ha & Yield/ TCH & Yield/TSH & $\begin{array}{c}\text { Population/ } \\
1000 / \text { ha }\end{array}$ \\
\hline 0.00 & 164.84 & 25.62 & 93.60 \\
28.00 & 167.17 & 24.86 & 100.67 \\
57.00 & 169.65 & 24.07 & 99.67 \\
86.00 & 152.26 & 21.95 & 89.76 \\
114.00 & 170.55 & 25.33 & 86.19 \\
\hline Mean & 69.25 & 10.23 & 39.47 \\
\hline C. V\% & 5.08 & 4.92 & 9.15 \\
SE \pm & 1.76 & 0.26 & 1.81 \\
Sig. & ns & $* *$ & ns \\
\hline
\end{tabular}

Table 2. Effect of Sulfur levels on sugarcane, plant height $(\mathrm{cm})$, internodes no and stem thickness $(\mathrm{cm})$, Variety R579

\begin{tabular}{cccc}
\hline S levels kg/ha & Plant height & Internodes No. & Thickness (cm) \\
\hline 0.00 & 323.00 & 57.20 & 2.96 \\
28.00 & 317.25 & 23.75 & 2.85 \\
57.00 & 306.25 & 23.35 & 2.87 \\
86.00 & 303.75 & 23.60 & 2.99 \\
114.00 & 319.60 & 25.55 & 2.89 \\
\hline Mean & 313.97 & 57.09 & 2.91 \\
\hline C. V\% & 6.08 & 5.86 & 7.21 \\
SE \pm & 9.54 & 0.65 & 0.10 \\
Sig. & ns & ns & ns \\
\hline
\end{tabular}

\subsection{Cane Yield}

The field yield in terms of tons cane per hectare (TC/ha) and tons sugar per hectare (TS/ha) were shown in table 1 . Generally higher cane yields were recorded under treatment $114,57,28,0.0$ and $86 \mathrm{~kg} \mathrm{~S} / \mathrm{ha}$ respectively, and sugar yields were recorded under treatment $0.00,114,27,57$ and $86 \mathrm{~kg} \mathrm{~S} /$ ha respectively, while lower cane and sugar yields were recorded under treatment $86 \mathrm{~kg} \mathrm{~S} / \mathrm{ha}$.

Analysis of variance, showed that there were no significant differences among treatments with respect to both cane and sugar yields for all treatments.

Table 3. Effect of Sulfur levels on Sugarcane quality, Brix\% cane, Pol\% cane and Fiber\% cane, Variety R579

\begin{tabular}{cccc}
\hline S levels kg/ha & Brix\% cane & Pol\% cane & Fiber\% cane \\
\hline 0.00 & 18.64 & 17.23 & 13.02 \\
28.00 & 17.87 & 16.56 & 13.83 \\
57.00 & 17.28 & 15.95 & 14.73 \\
86.00 & 17.32 & 16.13 & 14.68 \\
114.00 & 18.08 & 16.61 & 13.87 \\
\hline Mean & 17.39 & 16.50 & 14.03 \\
\hline C. V\% & 6.63 & 5.46 & 9.114 \\
SE \pm & 0.59 & 0.45 & 0.66 \\
Sig. & Ns & Ns & Ns \\
\hline
\end{tabular}

Table 4. Effect of Sulfur Levels on Sugarcane ERSc, purity and moisture\% cane, Variety R 579

\begin{tabular}{cccc}
\hline S levels kg/ha & ERSc & Purity & Moisture\% \\
\hline 0.00 & 15.53 & 92.51 & 68.35 \\
28.00 & 14.87 & 92.67 & 68.30 \\
57.00 & 14.22 & 92.30 & 68.00 \\
86.00 & 14.47 & 93.32 & 68.00 \\
114.00 & 14.85 & 91.98 & 68.05 \\
\hline Mean & 14.79 & 92.55 & 68.14 \\
\hline C. V\% & 5.58 & 1.59 & 1.21 \\
SE \pm & 0.41 & 0.73 & 0.41 \\
Sig. & ns & ns & ns \\
\hline
\end{tabular}

\section{Conclusions}

In conclusion the study revealed that:

$\checkmark$ Sulfur had a positive impact on sugarcane yield/hectare, except $86 \mathrm{~kg} /$ hectare there is a clear decrease in production compared to (control) and the same impact on plant density and plant height.

$\checkmark$ Control gave the highest yield of sugar/ hectare, then $114,28,57$ and 86 respectively.

$\checkmark$ There were insignificant differences between the means of the internodes number and plant height of all treatments.

$\checkmark \quad$ The Sulfur application gave significantly different in the total soluble solids (Brix\% cane) but there were insignificant differences among means of (Pol\% cane, Fiber $\%$ cane, extracting reducing sucrose ERSc, purity $\%$ and moisture $\%$ ). 


\section{REFERENCES}

[1] Ali, O.A. (1986) Sugarcane Response to Applied Potasium at Different Potassium Levels at Kenana Sugar Company Ltd. University Of Khartoum.

[2] AW, W., PW, M. and JH, P. (2005) Sustainable nutrient management-delivering the message to the Australian sugar industry. In: Proc S Afr Sug Technol Ass. 2005 p. 206.

[3] BL, S., AW, W., PW, M. and JH, P. (2005) Sustainable nutrient management-delivering the message to the Australian sugar industry. In: Proc S Afr Sug Technol Ass. 2005 p. 206.

[4] Ceccotti, S. (1996) Plant nutrient sulphur-a review of nutrient balance, environmental impact and fertilizers. In: Fertilizers and Environment. Springer. pp. 185-193.

[5] Humbert, R.. (1968) The growing of Sugarcane. Elsevier, pob. co., Amesterdam.

[6] Jannoo, N., Grivet, L., Chantret, N., Garsmeur, O., Glaszmann, J.C., Arruda, P. and D'Hont, A. (2007) Orthologous comparison in a gene-rich region among grasses reveals stability in the sugarcane polyploid genome. The Plant
Journal. 50, 574-585.

[7] Jeschke, M. and Diedrick, K. (2010) Sulfur fertility for crop production. Crop Insights. 20.

[8] Ming, R., Moore, P.H., Wu, K., D Hont, A., Glaszmann, J.C., Tew, T.L., Mirkov, T.E., Da Silva, J., Jifon, J., Rai, M. (2006) Sugarcane improvement through breeding and biotechnology. Plant breeding reviews. 2715.

[9] Randall, P., Wang, Q., Hocking, P. and Pinkerton, A. (1997) Critical values for sulfur in young plants of oilseed rape (Brassica napus L.) determined with reference to dry weight, leaf area and specific leaf weight. In: Plant Nutrition for Sustainable Food Production and Environment. Springer. pp. 335-339.

[10] Shrift, A. (1961) Biochemical interrelations between selenium and sulfur in plants and microorganisms. In: Ha. Proc. 1961 pp. 695-702.

[11] Tisdale, S.L., Nelson, W.L., Beaton, J.D. and Halvin, J.D (1985) Soil fertility and fertilizers. Collier Macmillan Publishers. 